\section{Occurrence of a Monogenean Gill Parasite Pseudorhabdosynochus epinepheli on Red Spotted Grouper Epinephelus akaara and Its Experimental Treatment by Hydrogen Peroxide Bathing}

\author{
Tadashi Isshiki $^{1 *}$, Taizou Nagano ${ }^{2}$ and \\ Katsuhiro Miki $^{2}$ \\ ${ }^{1}$ Graduate School of Bioresouces, Mie University, \\ Tsu, Mie 514-8507, Japan \\ ${ }^{2}$ Kagawa Prefectural Fisheries Experiment Station, \\ Takamatsu, Kagawa 761-0111, Japan
}

(Received Octorber 6, 2006)

\begin{abstract}
Since 1997, infection of a monogenean gill parasite Pseudorhabdosynochus epinepheli has been occurring in red spotted grouper Epinephelus akaara at the Kagawa Prefectural Sea-Farming Center, Japan. The efficacy of hydrogen peroxide $\left(\mathrm{H}_{2} \mathrm{O}_{2}\right)$ bathing was examined in vivo. Bathing in a $700 \mathrm{ppm} \mathrm{H}_{2} \mathrm{O}_{2}$ solution for $45 \mathrm{~min}$ at 10 or $15^{\circ} \mathrm{C}$, or for $15 \mathrm{~min}$ at 20 or $25^{\circ} \mathrm{C}$, with infected fish of $230-2100 \mathrm{~g}$ in body weight, resulted in $100 \%$ mortality of $P$. epinepheli on the gills. Mortality occurred in fish (550$1730 \mathrm{~g}$ ) bathed for $30 \mathrm{~min}$ or longer at $25^{\circ} \mathrm{C}$, but not in fish bathed for at least $60 \mathrm{~min}$ at 10,15 or $20^{\circ} \mathrm{C}$. Results indicate that chemotherapy with $\mathrm{H}_{2} \mathrm{O}_{2}$ has a high potential as an effective treatment for $P$. epinepheli infection in red spotted grouper.
\end{abstract}

Key words: Pseudorhabdosynochus epinepheli, Monogenea, hydrogen peroxide, Epinephelus akaara, red spotted grouper

The red spotted grouper Epinephelus akaara belonging to the order Perciformes is distributed mainly in coastal waters off southwestern Japan and the southern Korean Peninsula ${ }^{1)}$. In Japan, seed production for stock enhancement and aquaculture has been developing in a number of hatcheries in southwestern regions, including Kagawa Prefecture, owing to its high commercial value. Since 1997, infection of a monogenean Pseudorhabdosynochus epinepheli on the gills of red spotted grouper has been occurring at the Kagawa Prefectural Sea-Farming Center. Bathing in hydrogen peroxide $\left(\mathrm{H}_{2} \mathrm{O}_{2}\right)$ is an effective treatment for monogenean infections, such as Heterobothrium okamotoi and

\footnotetext{
* Corresponding author

E-mail: isshiki@bio.mie-u.ac.jp
}

Neobenedenia girellae in tiger puffer Takifugu rubripes, Benedenia seriolae in Seriola spp., and Bivagina tai in red sea bream Pagrus major ${ }^{2}$. $\quad \mathrm{A} \mathrm{H}_{2} \mathrm{O}_{2}$ bath medicine (Marine Sour SP-30; Katayama Kagaku Kogyo Kenkyujyo, Japan) is commercially available for treatment of these parasitic diseases in Japan*. In this paper, we describe the occurrence of $P$. epinepheli in red spotted grouper at the Kagawa Prefectural Sea-Farming Center and in vivo experiments on the efficacy of $\mathrm{H}_{2} \mathrm{O}_{2}$ bathing on the gill parasite.

\section{Materials and Methods}

Red spotted groupers (230-2100 g in body weight (BW)), naturally infected with $P$. epinepheli, were obtained from the Seto Inland Sea of Japan and reared at the Kagawa Prefectural Sea-Farming Center for 1 year or longer. Prior to use all experimental fish were individually tagged.

The efficacy of bathing in $700 \mathrm{ppm} \mathrm{H}_{2} \mathrm{O}_{2}$ against $P$. epinepheli was investigated at four different temperatures $\left(10,15,20\right.$ and $\left.25^{\circ} \mathrm{C}\right)$. Twenty fish were bathed in $500 \mathrm{~L}$ of seawater containing $700 \mathrm{ppm} \mathrm{H}_{2} \mathrm{O}_{2}$, which was prepared with a $\mathrm{H}_{2} \mathrm{O}_{2}$ chemical $(35 \%$ solution; KemiraUbe Ltd., Japan), with gentle aeration at the appropriate temperature. Five fish were transferred to new tanks at 15-min intervals up to $60 \mathrm{~min}$ and maintained in $500 \mathrm{~L}$ of seawater without $\mathrm{H}_{2} \mathrm{O}_{2}$ at the same temperatures. Three $\mathrm{h}$ after transfer of treated fish, a piece of the gill filaments was excised from the outermost gill arch of each fish and examined microscopically. Live or dead worms on the gills were counted separately: swollen nonmotile worms were considered to be dead based on our preliminary experiments (data not shown). Two control groups of five fish were bathed in seawater without $\mathrm{H}_{2} \mathrm{O}_{2}$ for $60 \mathrm{~min}$ at 10 or $20^{\circ} \mathrm{C}$ and gill filaments examined at 3 $\mathrm{h}$ post-treatment, as in the experimental groups. Abnormalities and mortality of experimental and control fish were recorded during treatment and the 3-h followup. Surviving fish in each group were reared in landbased tanks with a flow-through seawater system at above $15^{\circ} \mathrm{C}$ with feeding, and clinical signs and occurrence of infectious diseases monitored for $2 \mathrm{wk}$.

\section{Results and Discussion}

Occurrences of $P$. epinepheli in the grouper at the Kagawa Prefecture Sea-Farming Center

The occurrence of $P$. epinepheli was first found on the gills of brood stocks of red spotted grouper (approximately $500-1000 \mathrm{~g} \mathrm{BW}$ ), which had been reared in landbased tanks supplied with heated water $\left(15^{\circ} \mathrm{C}\right)$ at the

\footnotetext{
* The Ministry of Agriculture, Forestry and Fisheries of Japan (2006): Fish drug administrating for fish farmers, 19th ed., 20 p. (In Japanese)
} 


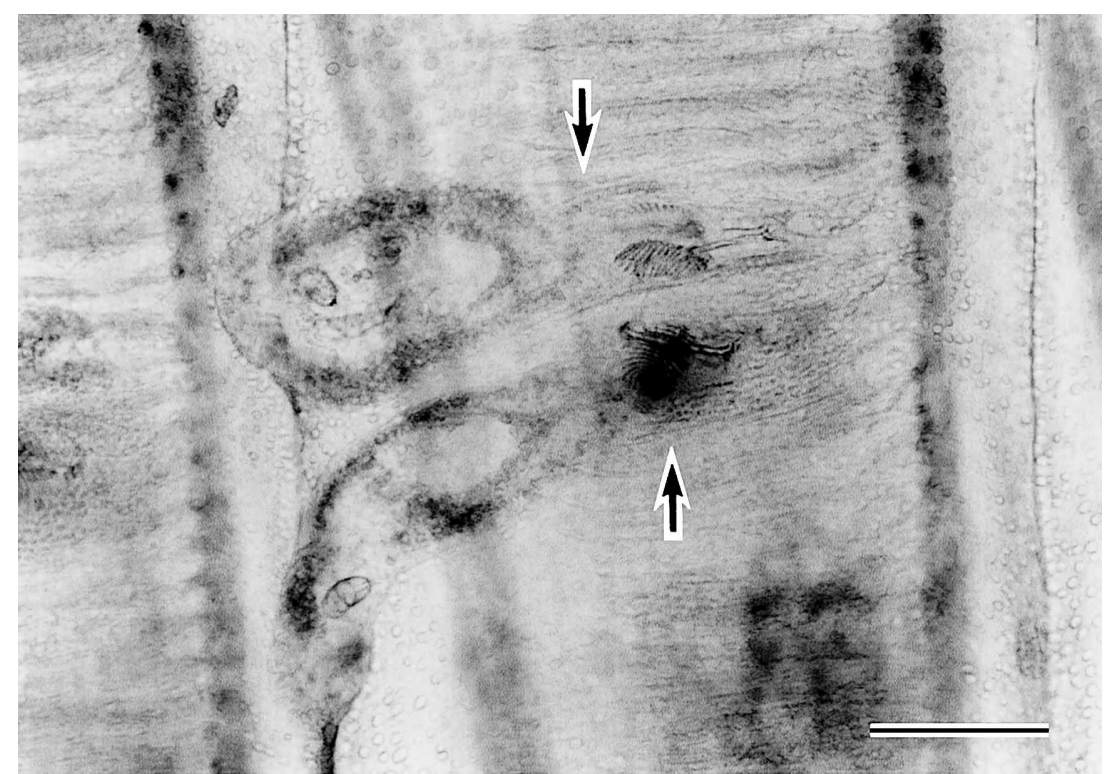

Fig. 1. Light micrograph of the gill of a red spotted grouper infected with Pseudorhabdosynochus epinepheli. Parasites (arrows) attach to the gill filaments by hooks. Scale bar $=0.2 \mathrm{~mm}$.

Kagawa Prefecture Sea-Farming Center in the winter of 1997. Since then, this parasite has been occurring on adult and juvenile groupers at the same hatchery almost throughout the year, where water temperatures ranged from about 10 to $25^{\circ} \mathrm{C}$. It has caused moderate mortalities in the juveniles.

Infected fish commonly show operculum-rubbing against tank walls leading to abrasion and hemorrhage on the skin of the operculum or body surface followed by occasional secondary infection with Vibrio spp. Heavily infected fish become lethargic and float near the water surface or remain on the bottom. They exhibit a whitish slime over the entire body surface, plus pale gills and internal organs due to diminished appetite. The gills or body surface of these weakened fish are occasionally infected with other ectoparasites, such as Benedenia sp. and Trichodina sp. In spawning seasons, egg production from weakened brood stocks due to heavy infection is very low.

In an outbreak in 1999, $P$. epinepheli was noticed in fish a few days after being introduced to the hatchery from the Inland Sea, suggesting that wild-origin brood stock is a possible source of $P$. epinepheli infection. The parasite attached to the gill filaments by hooks at densities of 5-500 individuals per 100 gill filaments (Fig. 1). Intensity of infection tends to be low at low water temperatures (around $10^{\circ} \mathrm{C}$ ) but increases gradually from late spring to summer when water temperatures range from about 15 to $25^{\circ} \mathrm{C}$.

\section{Treatments of $P$. epinepheli infection by $\mathrm{H}_{2} \mathrm{O}_{2}$ bathing}

The effect of $\mathrm{H}_{2} \mathrm{O}_{2}$ bathing on $P$. epinepheli and host fish is shown in Table 1. Treatments at 10 and $15^{\circ} \mathrm{C}$ showed a similar effect. Briefly, $100 \%$ mortality of worms occurred in the experimental groups bathed for 45 and $60 \mathrm{~min}$, but not in those bathed for 15 and 30 min. No treated fish died during or after treatments. On the other hand, treatments at 20 and $25^{\circ} \mathrm{C}$ showed a $100 \%$ mortality of the parasite after a $15-$ min bath as well as in longer bathing. The number of worms on the gills at $3 \mathrm{~h}$ post-treatment at $25^{\circ} \mathrm{C}$ was much lower than at other temperatures. Note that the intensity of infection showed little difference within the experimental groups before treatments (data not shown). Detachment of dead worms appears to occur relatively quickly with bathing at $25^{\circ} \mathrm{C}$, although detachment of a small number of dead worms might also occur with powerless treatment at $10^{\circ} \mathrm{C}$ for 15 or $30 \mathrm{~min}$, or at $15^{\circ} \mathrm{C}$ for 15 or 30 min. Because it is desirable that a single treatment kills all worms on the gills of adult groupers to maintain good husbandry without handling of spawners during the spawning season, efficacy was evaluated only by mortality of worms remaining on the gills after treatments in the present study.

In bathing treatment at $20^{\circ} \mathrm{C}$ for $60 \mathrm{~min}$, some fish became inactive after $45 \mathrm{~min}$, followed by lying on the bottom, but no mortality occurred during or after treatment. In contrast, toxicity of the $\mathrm{H}_{2} \mathrm{O}_{2}$ against the host fish was noticeable at $25^{\circ} \mathrm{C}$. Treatment at $25^{\circ} \mathrm{C}$ resulted in mortalities of 60,100 and $100 \%$ after bathing for 30, 45 and $60 \mathrm{~min}$, respectively. Dead fish (550$1730 \mathrm{~g} \mathrm{BW}$ ) commonly displayed petechia and brown discoloration of the gills, indicating damages due to $\mathrm{H}_{2} \mathrm{O}_{2}$ exposure.

In the control groups, all examined worms were active at $3 \mathrm{~h}$ post-treatment and no abnormalities or mortality were recorded in the host fish. In fish surviving the treatments, the characteristic sign of infected fish, oper- 
Table 1. Results of treatments of Pseudorhabdosynochus epinepheli on red spotted grouper by 700 ppm hydrogen peroxide bathing

\begin{tabular}{|c|c|c|c|c|c|c|c|c|c|}
\hline \multirow{2}{*}{$\begin{array}{c}\text { Bathing } \\
\text { water temp. } \\
\left({ }^{\circ} \mathrm{C}\right)\end{array}$} & \multirow{2}{*}{$\begin{array}{c}\text { Bathing } \\
\text { period } \\
\text { (min) }\end{array}$} & \multirow{2}{*}{$\begin{array}{c}\text { Fish } \\
\text { No. }\end{array}$} & \multicolumn{2}{|c|}{ Percent mortality of } & \multirow{2}{*}{$\begin{array}{c}\text { Bathing } \\
\text { water temp. } \\
\left({ }^{\circ} \mathrm{C}\right)\end{array}$} & \multirow{2}{*}{$\begin{array}{c}\text { Bathing } \\
\text { period } \\
\text { (min) }\end{array}$} & \multirow{2}{*}{$\begin{array}{c}\text { Fish } \\
\text { No. }\end{array}$} & \multicolumn{2}{|c|}{ Percent mortality of } \\
\hline & & & Worms ${ }^{* 1}$ & Host fish & & & & Worms & Host fish \\
\hline \multirow[t]{13}{*}{10} & \multirow[t]{3}{*}{15} & $\begin{array}{l}1 \\
2\end{array}$ & $\begin{array}{l}33(1 / 3)^{* 2} \\
33(1 / 3)\end{array}$ & $0(0 / 5)^{* 3}$ & \multirow[t]{13}{*}{20} & \multirow[t]{3}{*}{15} & $\begin{array}{l}1 \\
2\end{array}$ & $\begin{array}{l}100(13 / 13) \\
100(2 / 2)\end{array}$ & \multirow[t]{3}{*}{$0(0 / 5)$} \\
\hline & & 3 & $40(6 / 15)$ & & & & 3 & $100(7 / 7)$ & \\
\hline & & $\begin{array}{l}4 \\
5\end{array}$ & $\begin{array}{l}0(0 / 1) \\
0(0 / 2)\end{array}$ & & & & $\begin{array}{l}4 \\
5\end{array}$ & $\begin{array}{l}100(18 / 18) \\
100(17 / 17)\end{array}$ & \\
\hline & \multirow[t]{4}{*}{30} & $\begin{array}{l}1 \\
2\end{array}$ & $\begin{array}{c}47(8 / 17) \\
100(5 / 5)\end{array}$ & $0(0 / 5)$ & & \multirow[t]{4}{*}{30} & $\begin{array}{l}1 \\
2\end{array}$ & $\begin{array}{l}100(3 / 3) \\
100(4 / 4)\end{array}$ & \multirow[t]{4}{*}{$0(0 / 5)$} \\
\hline & & 3 & $46(6 / 13)$ & & & & 3 & $100(15 / 15)$ & \\
\hline & & 4 & $20(1 / 5)$ & & & & 4 & $100(3 / 3)$ & \\
\hline & & 5 & $17(1 / 6)$ & & & & 5 & $100(4 / 4)$ & \\
\hline & \multirow[t]{3}{*}{45} & $\begin{array}{l}1 \\
2\end{array}$ & $\begin{array}{l}100(6 / 6) \\
100(30 / 30)\end{array}$ & $0(0 / 5)$ & & \multirow[t]{3}{*}{45} & $\begin{array}{l}1 \\
2\end{array}$ & $\begin{array}{l}100(3 / 3) \\
100(9 / 9)\end{array}$ & \multirow[t]{3}{*}{$0(0 / 5)$} \\
\hline & & 3 & $100(1 / 1)$ & & & & 3 & $100(1 / 1)$ & \\
\hline & & $\begin{array}{l}4 \\
5\end{array}$ & $\begin{array}{l}100(11 / 11) \\
100(22 / 22)\end{array}$ & & & & $\begin{array}{l}4 \\
5\end{array}$ & $\begin{array}{l}100(9 / 9) \\
100(17 / 17)\end{array}$ & \\
\hline & \multirow[t]{3}{*}{60} & $\begin{array}{l}1 \\
2\end{array}$ & $\begin{array}{l}100(5 / 5) \\
100(14 / 14)\end{array}$ & $0(0 / 5)$ & & \multirow[t]{3}{*}{60} & $\begin{array}{l}1 \\
2\end{array}$ & $\begin{array}{l}100(26 / 26) \\
100(10 / 10)\end{array}$ & \multirow[t]{3}{*}{$0(0 / 5)$} \\
\hline & & 3 & $100(9 / 9)$ & & & & 3 & $100(3 / 3)$ & \\
\hline & & $\begin{array}{l}4 \\
5\end{array}$ & $\begin{array}{l}100(13 / 13) \\
100(23 / 23)\end{array}$ & & & & $\begin{array}{l}4 \\
5\end{array}$ & $\begin{array}{l}100(4 / 4) \\
100(5 / 5)\end{array}$ & \\
\hline \multirow[t]{4}{*}{ Control } & 60 & 1 & $0(0 / 29)$ & $0(0 / 5)$ & \multirow[t]{4}{*}{ Control } & \multirow[t]{4}{*}{60} & 1 & $0(0 / 11)$ & \multirow[t]{4}{*}{$0(0 / 5)$} \\
\hline & & 2 & $0(0 / 21)$ & & & & 2 & $0(0 / 12)$ & \\
\hline & & 3 & $0(0 / 11)$ & & & & 3 & $0(0 / 30)$ & \\
\hline & & $\begin{array}{l}4 \\
5\end{array}$ & $\begin{array}{l}0(0 / 24) \\
0(0 / 34)\end{array}$ & & & & $\begin{array}{l}4 \\
5\end{array}$ & $\begin{array}{l}0(0 / 24) \\
0(0 / 35)\end{array}$ & \\
\hline \multirow[t]{15}{*}{15} & 15 & $\begin{array}{l}1 \\
2\end{array}$ & $\begin{array}{l}0(0 / 16) \\
0(0 / 14)\end{array}$ & $0(0 / 5)$ & 25 & 15 & $\begin{array}{l}1 \\
2\end{array}$ & $\begin{array}{r}100(4 / 4) \\
N^{* 4}(0 / 0)\end{array}$ & $0(0 / 5)$ \\
\hline & & 3 & $0(0 / 30)$ & & & & 3 & $100(4 / 4)$ & \\
\hline & & $\begin{array}{l}4 \\
5\end{array}$ & $\begin{array}{l}0(0 / 2) \\
0(0 / 8)\end{array}$ & & & & $\begin{array}{l}4 \\
5\end{array}$ & $\begin{array}{l}100(2 / 2) \\
100(2 / 2)\end{array}$ & \\
\hline & 30 & $\begin{array}{l}1 \\
2\end{array}$ & $\begin{array}{r}94(16 / 17) \\
100(16 / 16)\end{array}$ & $0(0 / 5)$ & & 30 & $\begin{array}{l}1 \\
2\end{array}$ & $\begin{array}{l}100(3 / 3) \\
100(2 / 2)\end{array}$ & $60(3 / 5)$ \\
\hline & & 3 & $100(7 / 7)$ & & & & 3 & ND $(0 / 0)$ & \\
\hline & & 4 & $100(18 / 18)$ & & & & 4 & ND $(0 / 0)$ & \\
\hline & & 5 & $91(20 / 22)$ & & & & 5 & ND $(0 / 0)$ & \\
\hline & 45 & $\begin{array}{l}1 \\
2\end{array}$ & $\begin{array}{l}100(27 / 27) \\
100(17 / 17)\end{array}$ & $0(0 / 5)$ & & 45 & $\begin{array}{l}1 \\
2\end{array}$ & $\begin{array}{l}100(8 / 8) \\
\text { ND }(0 / 0)\end{array}$ & $100(5 / 5)$ \\
\hline & & 3 & $100(18 / 18)$ & & & & 3 & $100(2 / 2)$ & \\
\hline & & 4 & $100(15 / 15)$ & & & & 4 & $100(2 / 2)$ & \\
\hline & & 5 & $100(50 / 50)$ & & & & 5 & ND $(0 / 0)$ & \\
\hline & 60 & $\begin{array}{l}1 \\
2\end{array}$ & $\begin{array}{l}100(33 / 33) \\
100(47 / 47)\end{array}$ & $0(0 / 5)$ & & 60 & $\begin{array}{l}1 \\
2\end{array}$ & $\begin{array}{l}\text { ND }(0 / 0) \\
\text { ND }(0 / 0)\end{array}$ & $100(5 / 5)$ \\
\hline & & 3 & $100(5 / 5)$ & & & & 3 & $100(1 / 1)$ & \\
\hline & & 4 & $100(35 / 35)$ & & & & 4 & $100(1 / 1)$ & \\
\hline & & 5 & $100(154 / 154)$ & & & & 5 & ND $(0 / 0)$ & \\
\hline
\end{tabular}

*1 The mortality was determined by the microscopic examinations of worms on the gills which were excised from each treated fish at $3 \mathrm{~h}$ post-treatment.

*2 Number of dead worms/number of worms on the gills examined.

*3 Number of dead fish/number of experimental fish.

${ }^{* 4}$ Not determined.

culum-rubbing, disappeared. Furthermore, treated fish became active and appetites improved, resulting in good husbandry conditions at $1 \mathrm{wk}$ post-treatments. No clinical signs of disease were evident 2 wk after treatments.

The study shows that the bathing in $700 \mathrm{ppm} \mathrm{H}_{2} \mathrm{O}_{2}$ for $15 \mathrm{~min}$ at 20 or $25^{\circ} \mathrm{C}$, or for $45 \mathrm{~min}$ at 10 or $15^{\circ} \mathrm{C}$ is effective in controlling $P$. epinepheli infection in adult red spotted grouper of 200-2000 g in body weight. However, treatment at $25^{\circ} \mathrm{C}$ for $30 \mathrm{~min}$ and longer can cause mortality of above $60 \%$ in the host fish and, thus, requires rapid transfer of treated fish from the $\mathrm{H}_{2} \mathrm{O}_{2}$ solution at the end of bathing in the field trial. In general, host toxicity of $\mathrm{H}_{2} \mathrm{O}_{2}$ depends on life stage of the fish ${ }^{3)}$, therefore, further studies are required to clarify the toxic- 
ity of the $\mathrm{H}_{2} \mathrm{O}_{2}$ bathing on juvenile red spotted grouper. In conclusion, chemotherapy with $\mathrm{H}_{2} \mathrm{O}_{2}$ has a high potential as an effective treatment for $P$. epinepheli infection in red spotted grouper.

\section{Acknowledgements}

We thank Dr. Kazuo Ogawa and Dr. Tomoyoshi Yoshinaga of The University of Tokyo for identifying $P$. epinepheli and critically reading the manuscript, respectively.

\section{References}

1) Masuda, H., K. Amaoka, C. Araga, T. Ueno and T. Yoshino (1984): The fishes of the Japanese Archipelago. Tokai University Press, Tokyo, 448 p. (In Japanese) 2 2) Ogawa, K. (2004): Monogenean infection. In "Infectious and parasitic diseases of fish and shellfish" (ed. by H. Wakabayashi and K. Muroga). Kouseisha-Kouseikaku, Tokyo. pp. 353-379. (In Japanese) 3) Rach, J. J., T. M. Schreier, G. E. Howe and S. D. Redman (1997): Progressive Fish-Culturist, 59, 41-46. 